BY JOHN F. HARVEY

\title{
Variety in the Experience of
}

\section{Chief Librarians}

$\mathrm{H}^{\circ}$

OW MANY CHIEF LIBRARIANS have worked as student assistants? How many chief librarians have seen how the other half lives and worked as professional assistants or department heads? How many of the careers of chief librarians have been enriched by a variety of experience including work in other occupations, work in other kinds and sizes of libraries?

In preparing for library leadership, experience provides excellent training. McDiarmid has said, "There are three important factors in the development of library leaders: (1) personal qualities, (2) proper education, and (3) adequate experience." 1 This experience should be varied and should include good administrative experience, according to McDiarmid. But how many public and college library administrators have had such experience? How many are well prepared in this respect?

This article summarizes a larger study dealing with the experience patterns of librarians. Data were collected on 629 college librarians and 687 public librarians, all of whom were chief librarians. Senior college and university librarians, county, and public librarians were included. Data were collected from the biographies in Who's Who in Library Service. In essence, this article will attempt to describe the extent to which 1,316 chief librarians had a variety of experience.

1 E. W. McDiarmid "Place of Experience in Developing College and University Librarians," Library Quarterly, XII (1942), 614.

Dr. Harvey is Librarian, State Teachers College, Pittsburg, Kansas.
The first section will describe the variety of preparatory experience enjoyed by the chief librarians in other occupations, in non-administrative work, and in other kinds of libraries, position levels, and library sizes.

\section{KIND OF WORK MOBILITY}

How many had worked in other occupations? Since the study found the librarians to average twenty-six (college) and twenty-four (public) years of age upon taking the first professional library position, it is obvious that they spent some time in their early twenties in some other line of work. As a matter of fact, these librarians, in their first full time positions, were working outside librarianship in nearly one-third (public) and one-half (college) of the cases. Consequently, the chances were no better than two in three for public and one in two for college librarians that librarianship was the first occupational choice. In fact, a few librarians had several jobs in other fields; 101 of the 1,316 librarians were still in another field in their third full time position. Average numbers of years spent in other fields were 4.7 for college and 1.8 for public librarians.

In all, 55 per cent of the college librarians and 37 per cent of the public librarians worked in other fields. Over one-fourth of the college librarians and one-sixth of the public librarians had had two or more positions in other fields, showing a sizable minority to have had a variety of work outside librarianship.

What kinds of work were performed? 
Positions in the education world, whether higher education, elementary, or secondary education dominated. Two of every five college and one of every four public librarians had worked in the education field. Business and other fields trailed with only about one in seven librarians working in these fields. Teaching in higher education was most popular with college librarians, since onefourth had done this, while teaching in elementary or secondary school was most popular with public librarians since one-fifth had done that. The emphasis on education is not surprising since the agencies most closely related in function to libraries are education agencies.

\section{KIND OF LIBRARY WORK}

Had experience been enriched with a variety of work in several different library departments? Variety of experience was not extensive in terms of having worked in full time positions in various types of library work (cataloging, children's, acquisitions, etc.). More than half of both groups had performed only one type of library work, administration. However, a fourth had had experience in two kinds of library work and a seventh had performed three or more kinds of library work. For the average librarian, this was not the varied experience which was considered desirable. Most of the various kinds of library work had never been performed by these librarians, at least on a full time basis. For both college and public librarians, the two most popular kinds of work performed, in addition to administration, were reference and cataloging. Circulation work and children's work (for public librarians) followed for small minorities. If there were educational advantages in having worked in several different kinds of library work, most of these librarians lacked them.

\section{KINDS OF LIBRARIES}

How many had worked in several kinds of libraries? Less than half, only 44 per cent, had worked in more than one kind of library (public, school, special, etc.). And only about a tenth had worked in three or more different kinds of libraries. The barrier of kind of library was apparently a difficult one to jump.

In what kinds of libraries had they worked? Both college and public library groups were represented in each of the five kinds of libraries studied-college, public, school, government, and special. There was no type in which some had not worked.

Aside from having worked in college libraries, the largest group of college librarians, 40 per cent, or almost half, had worked in public libraries. Only about one in nine had worked in either school or government libraries, and only one in twenty in special libraries. Public librarians, aside from having worked in public libraries, had worked most frequently in college libraries. About a third had worked there, one-seventh each in government and school libraries, and one-eleventh in special libraries.

\section{Position Level}

How varied was experience at different position levels? These chief librarians had enjoyed a greater variety of experience in terms of position level (chief librarian, assistant librarian, department head, etc.) than they had in most of the other categories examined. Two-thirds of the college librarians had worked at two or more position levels and three-fourths of the public librarians had done this. As many as twofifths of these librarians had worked at three or more position levels. Of course, all of these librarians had been chief librarians, the position level at which all were working when the data were col- 
lected. Experience at other position levels was well scattered. For college librarians, the second most frequent level was that of assistant librarian (involving 28 per cent), and for public librarians it was the professional assistant level ( 51 per cent).

Position level immediately prior to taking chief librarian's position. At what levels had these librarians worked immediately before their chief librarian's positions? Had this experience been in positions which would prove helpful to a chief librarian? One-fourth of the college and one-ninth of the public librarians had not been in library work at all in these previous positions. Instead, they had taken over as heads of libraries with no previous library experience. About one-fifth of the college and threetenths of the public librarians had been working as chief librarians, excellent experience. One-sixth of the college and one-fourth of the public librarians had previously worked as professional assistants.

In searching further for an answer to the question about experience before heading libraries, it would be desirable to ascertain the importance of the middle administrative ranks in providing experience for future administrators. Ideally, according to McDiarmid, the librarian's career should show experience at a middle administrative rank before he undertakes a top level position. ${ }^{2}$ However, only one-fourth of these librarians had been working in the middle administrative ranks (assistant librarian or department head) in previous positions. On the other hand, with the fact that another fourth had been chief librarians, we can conclude that half had been working previously in an administrative position of some kind, and this is probably as high a percentage as we can expect.

${ }^{2}$ Ibid., pp. $620-621$.

\section{Size OF LibRARY}

Librarians who had worked in more than one size of library. Almost half of the college librarians and a third of the public librarians had worked in only one size of library. But, one-fifth (college) and three-tenths (public) of these chief librarians had worked in three or more library sizes. The average librarian had worked in either one or two of the four size groups used, with public librarians having had a greater variety of experience than had college librarians. For public librarians, work was well divided among the four library sizes, but emphasized the small sizes for college librarians.

\section{Personal Characteristics}

This section will describe two interesting sidelights on experience: the personal characteristics of librarians with varied experience and the advancement levels they achieved. Can we identify those librarians who had had a greater variety of experience by their personal characteristics?

Sex. The sex differential was most important. Those with a variety of experience always included a significantly higher percentage of men than of women. This held for both college and public librarians. Therefore, in this sense, there is no question but that men were better prepared by their experience for administration and for top-level positions than were women, no matter how capable they were, nor how much innate ability they may have had.

Marital Status. Marital status also distinguished between those with a variety of experience and those without, though not as well as did sex. For the most part, the most mobile were to be thought of as married males and the least mobile as single females.

Education. Years of schooling or type of library school attended was frequent- 
ly a good way of identifying those with or without a variety of experience. The more years of schooling, or the fact of having attended a Type I library school (offering two or more years of schooling) was usually a distinguishing factor.

Experience. Were those with a greater variety of experience also the ones who had had more than average years of experience? Were variety and extent of experience highly correlated? Yes, they were. Years of library experience was closely associated with variety of experience.

How high in the advancement levels of the profession were these two groups of librarians? Were those with varied experience in "better" positions when the data were collected, than those with more limited experience? The answer was "yes." Variety of experience and advancement level in the profession correlated positively. Those chief librarians with more varied experience were found in the more responsible positions. Those with less varied experience were typically found in the poorer positions.

The college and public chief librar- ians in this study had had relatively little experience in terms of variety. They scored better in the areas of kind of work, position level, and library size, and worse in kind of library work and kind of library. In most of these categories, the typical librarian had worked in no more than one other kind of position beyond his latest position, and for some categories, not even that. Several personal characteristics were identified for the groups as well as their standings in the advancement levels of the profession.

These librarians, since they had had such limited experience, were not, for the most part, well trained in variety of experience. Nor were the librarians in the smaller group examined by McDiarmid. ${ }^{3}$ They had reached administrative positions of responsibility without the benefit of an enriching variety of experience. However, a minority of this group had had varied experience, in some cases, quite varied, and we may be thankful for this minority.

${ }^{3}$ Ibid., pp. 616-617.

\section{National Union Catalog - Subscription Price 1958-1962}

The cost of annual subscriptions to The National Union Catalog has been set at $\$ 260$ a year for the next five years. As in the two preceding years, there will be a single subscription price covering all issues-monthlies, quarterlies, and annual cumulations, including the following two parts, Library of Congress Catalog-Motion Pictures and Filmstrips and Music and Phonorecords. The price of all subscriptions will be the same regardless of the number of copies purchased by any single institution. Subscriptions should be directed to: Card Division, Library of Congress, Washington 25, D.C. The price may be charged against the accounts of subscribers to the card service; others must pay in advance by check or money order made payable to the Chief of the Card Division, Library of Congress. The quinquennial cumulation will be priced separately, as usual. 